\title{
重度の歯周炎における包括的アプローチ
}

\author{
羽兼 雅 広
}

\section{A Comprehensive Approach for a Case of Advanced Periodontal Disease}

\author{
Masahiro Hagane
}

\begin{abstract}
Advanced periodontal disease often compromises the tissues supporting the teeth, causing an increase in their mobility and movement. This causes a collapse of occlusion resulting from deterioration of occlusal support in the molar region and loss of anterior quidance, promoting a vicious cycle that leads to further collapse of the periodontal tissues.

In cases like this, periodontal and prosthetic treatment does not end with control of the inflammation, but also involves occlusal treatment that includes prosthetic restoration of missing teeth. In carrying out periodontal and prosthetic treatment, I feel it especially important to consider:

1. absolute control of inflammation, 2. establishment of the appropriate anterior guidance, and 3 . placement of vertical stops in the molar region.

I would like to report this case which involved advanced periodontal disease and temporomandibular joint dysfunction resulting from occlusal collapse owing to missing teeth in the molar region. Although the treatment was extremely difficult for me and took a long time, I feel the results were rather successful.
\end{abstract}

\section{はじめに}

重度の歯周炎に罹患した症例においては，歯の 支持組繊の破壊に伴い, 動摇性の増加そして歯の 位置異常等が生じてくる。これは，臼歯部の咬合 支持の低下,アンテリアーガイダンスの衰失などの 咬合の崩壊を生じさせ，さらに，このことが悪循 環として歯周組織の崩壊を助長することになる.

こういった症例においては, 歯周補経治療とし て，炎症抑制にとどまることなく，欠損補綴をも 含む咬合治療を行っていく事になる.

その為,筆者は歯周補綴治療を行なうにあたり，

\footnotetext{
* 東京都中央区開業
}

1 ．徽底的な炎症抑制，2．適正なアンテリアー ガイダンスの確立， 3 ． 臼歯部バーティカル・ス トップなどを特に留意すべき点であると考える。

本症例は重度の歯周炎に加え，臼歯部欠損によ る咬合崩壊からの㖽関節炎症を生じているもの で, 治療において困難をきわめ, 長い治療期間を 費やし，顎位の試行するに至った。一応の治療成 果を挙げられたと思われるので,ここに報告する.

\section{症例}

患 者: 女性, 初診時 47 歳.

初 診: 平成 3 年 8 月 20 日.

主 訴：左上のかぶせものがとれた。

既住歴：全身；胃潰瘍,血圧が少し高い.歯科； 


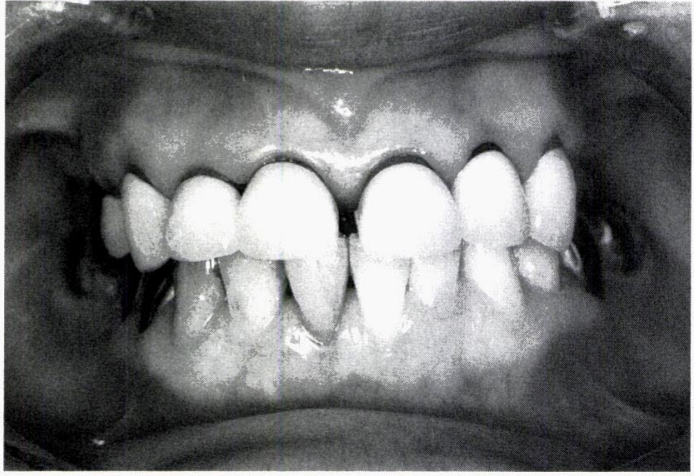

図 1

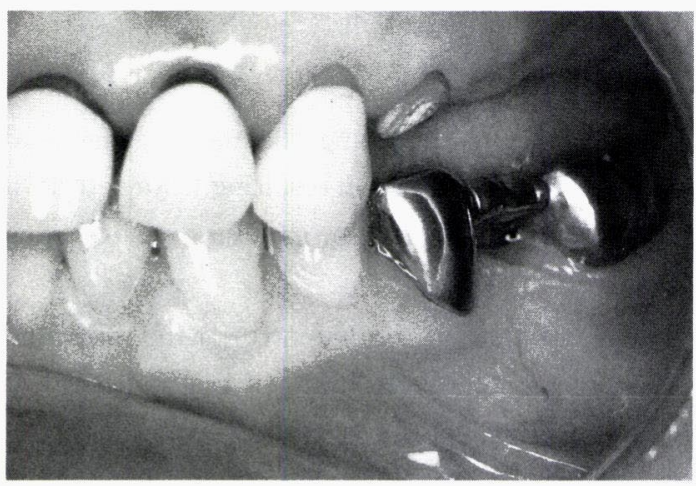

図 3

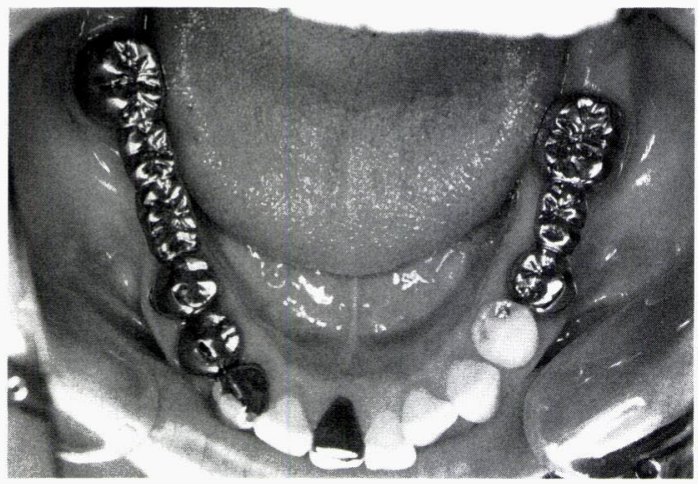

図 5

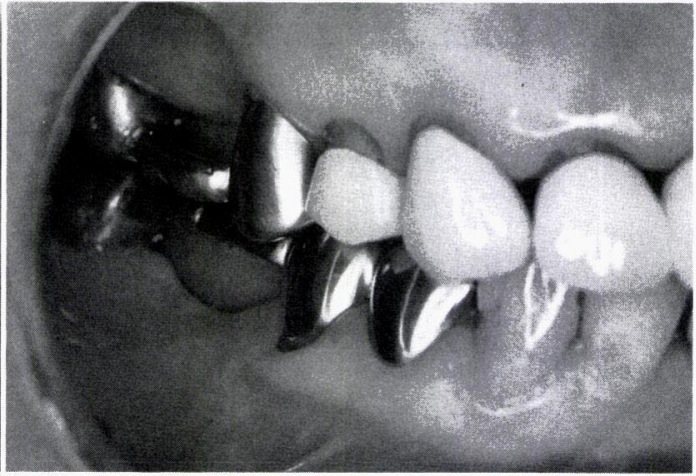

図 2

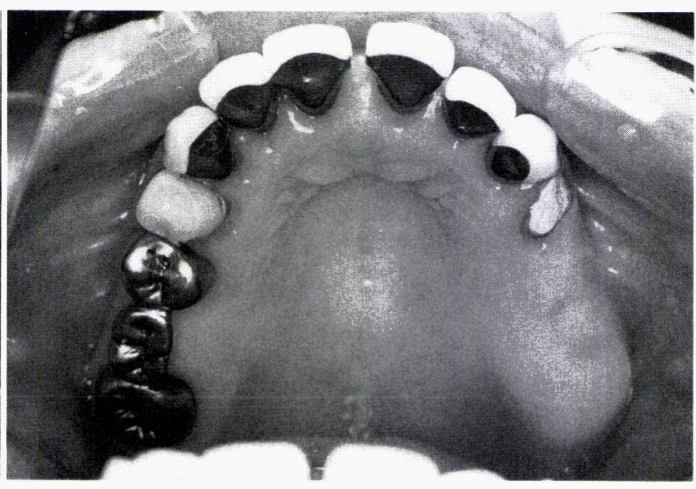

図 4

図 1〜5 初診時の口腔内の状態
子供の時から虫歯が多く成人してから徐々に抜歯 した. 上の冠は， 7 年以上前で 2 年くらい前から すき間があいてきた.ここ数年, 左の関節が痛い.

\section{現 症}

口腔内所見 : 左上臼歯部が欠損した状態でそ の他の臼歯部には不良の Bridge が装着されてい る。前歯部は正中にて破折しており, フレアーア ウトを生じている。また歯肉退縮, 根面カリエス
も認められる（図 1～5 ).

X 線所見：全体として骨吸収が著しく, 特に $\frac{5}{8} 7$ の状態が悪い. また上顎前歯部根尖にリー ジョンが認められる(図6).

顎関節所見：過去に左右ともクリックがあった が, 現在は両方ともない. 左側のみ, 開口中期お よび閉口初期にクレピタスがある。最大開口量は $30 \mathrm{~mm}$ で, 終期に左側のみかなりの疼痛がある。 


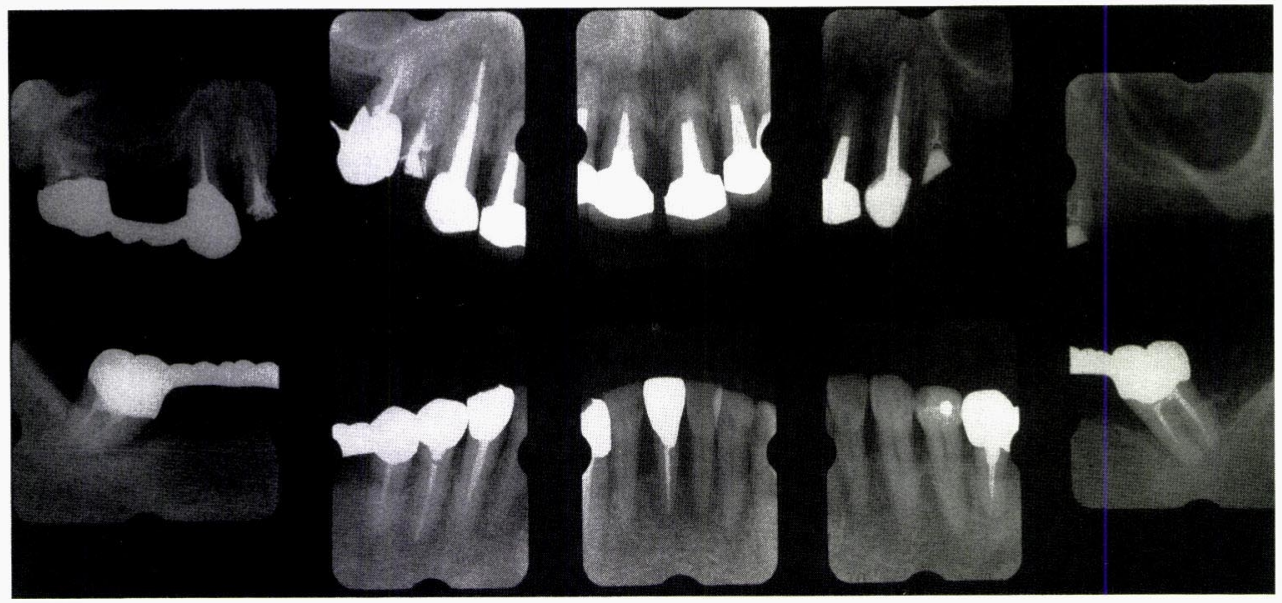

図 6 術前のX線写真, 特に $\frac{7}{8} 51 \mid$\begin{tabular}{l|l|l}
7 & $\frac{4}{7}$ \\
\hline
\end{tabular}

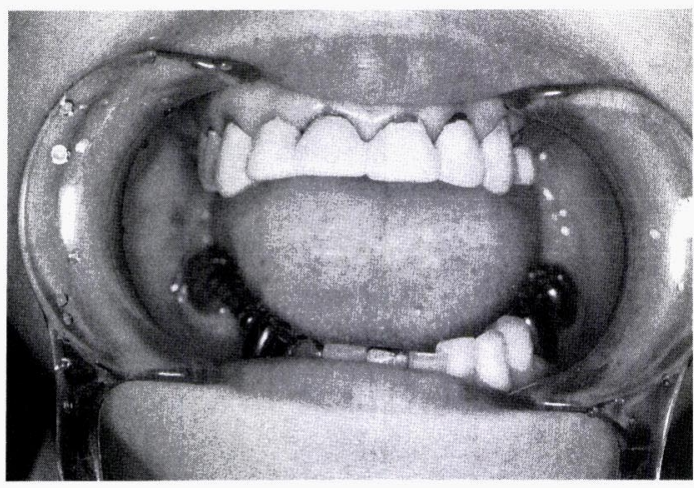

図 7 開口時，左側に偏位するとともに疼痛が 著しい。

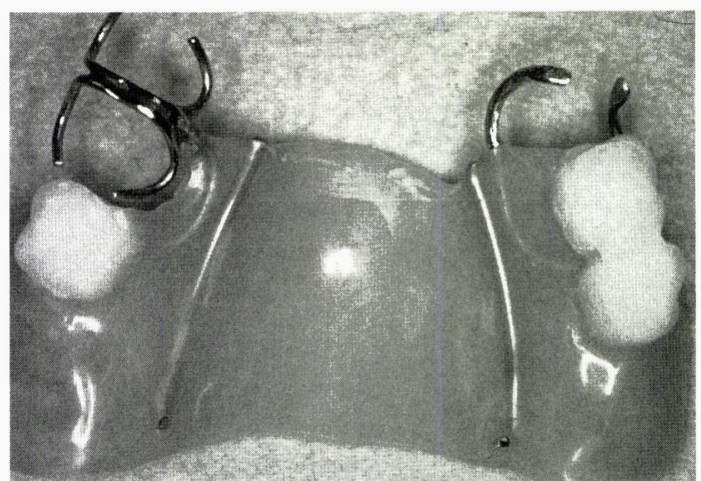

図 8 治療義歯を装着し咬合挙上を行なう.

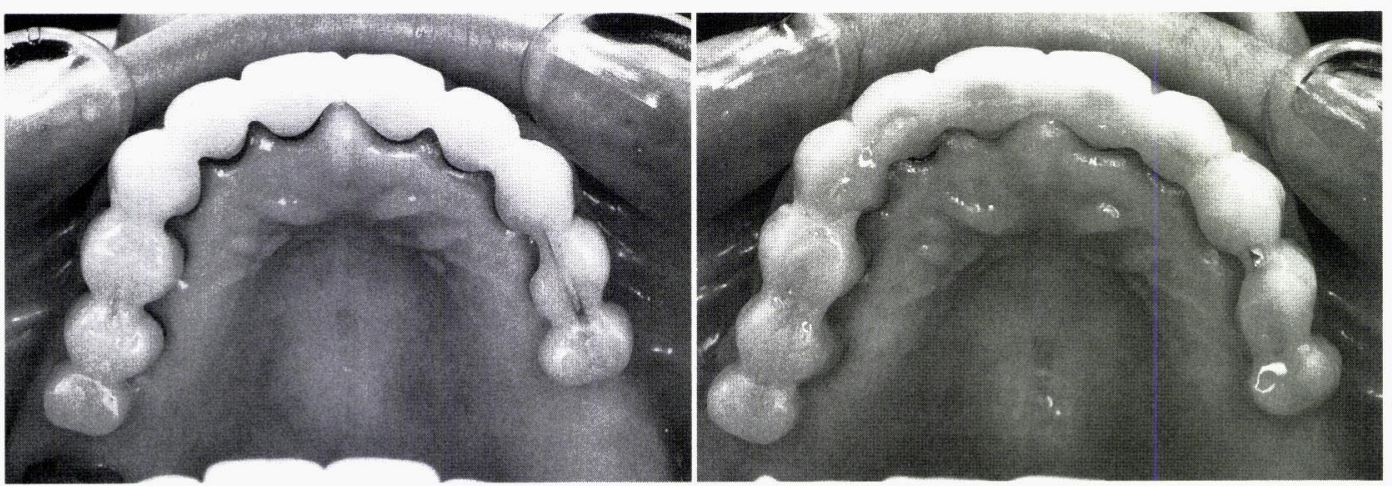

図 9 (左), 10 (右) 結果として延長タイプのクロスアーチスプリントとした。また試行錯誤の結 果，より緊密な咬合を与えると同時に，前歯部口蓋側をバーチカルストップ に加えた. 
開口時左側に下顎正中が偏位する(図 7 ). 前方運 動時も左側に疼痛がある. 丸茂の CCT によると 左側の可動性が大きいと考えられた。その他いく

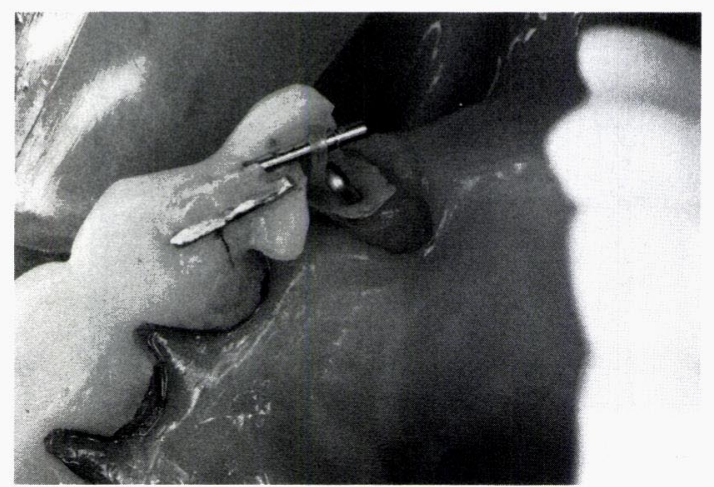

図 $11 \underline{5 \mid 4}$ は骨のレベリングのため廷出を行う.
つかの診査の結果, 現在この患者は左右とも off the disk であり, 左側は顎関節内障がかなり進み, 円板支持組織は伸展し弾力性を失い, 円板ももし かすると変形や断裂をきたしている可能性もある 状態と思われた。

\section{処置および経過}

この症例の治療ポイントとしては第 1 に，顎関 節の安定を考慮した咬合の再構成を行うというこ とがあげられる。それには先に述べたように臼歯 部バーチカルストップおよびアンテリアガイダン スの確立を行い，そして可能であれば関節円板の リキャプチャーも目標とする治療計画を立てた。 第 2 に, 重度に破壊された歯周組織に対して，歯 周外科を含む徹底的な治療を行なうことが必要で あった．以下に各項目別に説明したいと思う。
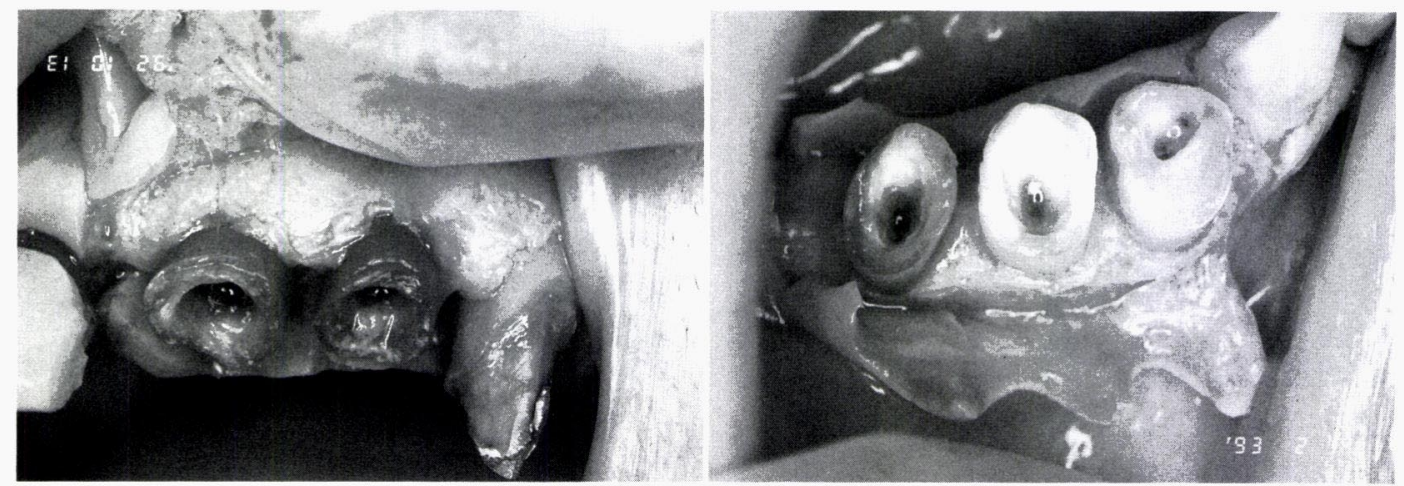

図 12(左)，13(右) 歯周外科時.

メインテナンスしやすい歯周環境をつくる.
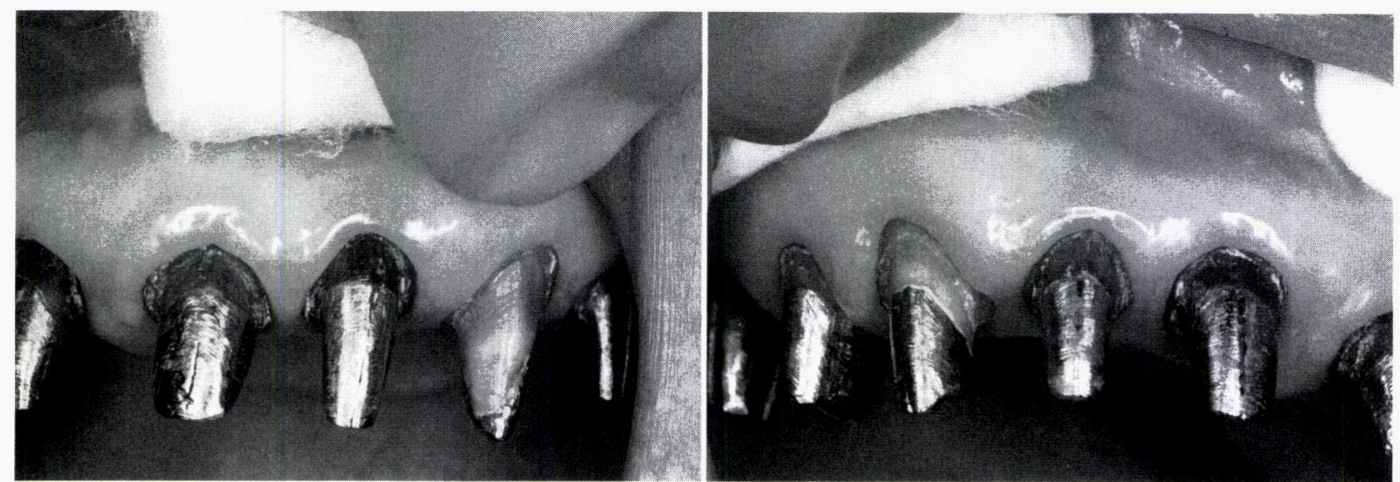

図 14(左)，15(右) 印象前の支台の状態.

著しい歯根の変色のため, 歯肉が少し黒ずんで見えるが炎症は全くない. 


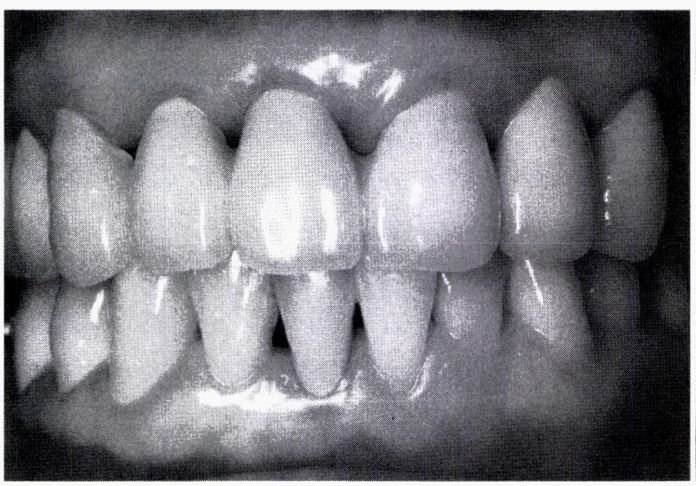

図 16

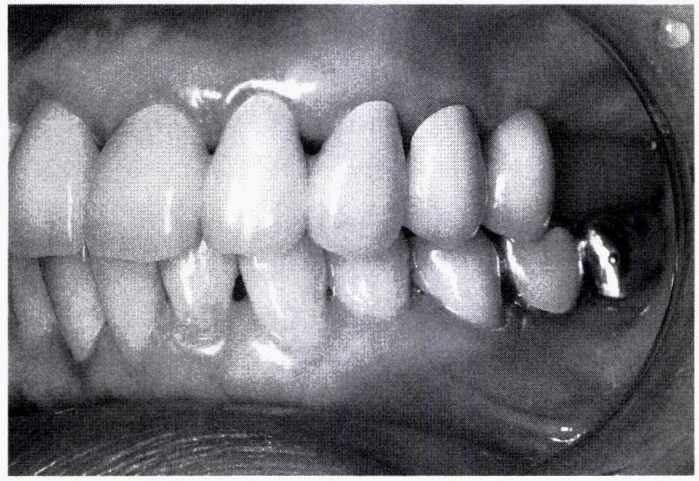

図 18

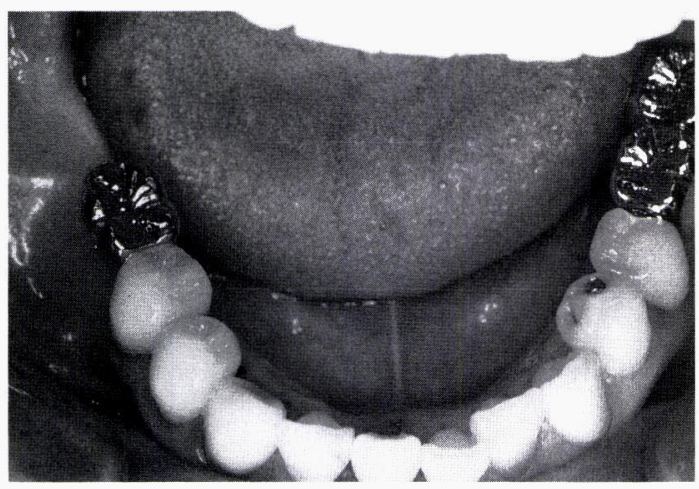

図 20

\section{1. 咬合再構成}

初期治療の一環として不良補緅物を除去し, プ ロビジョナルレストレーションを装着する.また， 咬合高径の回復のための治療用義歯を装着し咬合 挙上を行った(図 8 ). しかし, 患者は声学が趣味 で発音の変化の問題と, 装着感の点で義歯を強く 拒んだ.いくつか形を修正したが, 最終的には 1 歯ずつ延長したクロスアーチスプリントに変更し

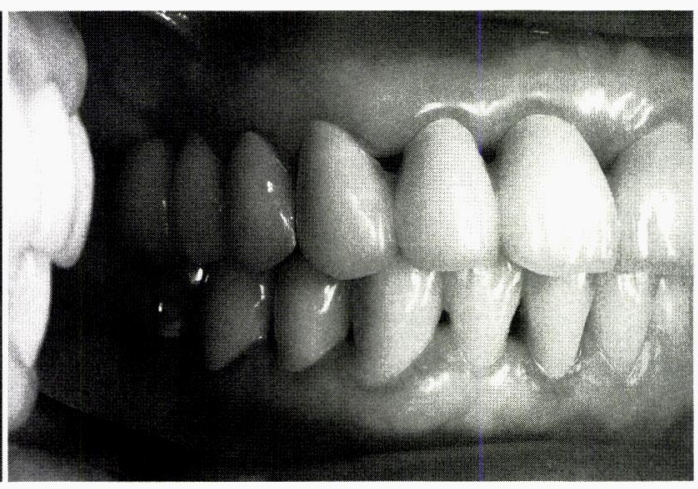

図 17

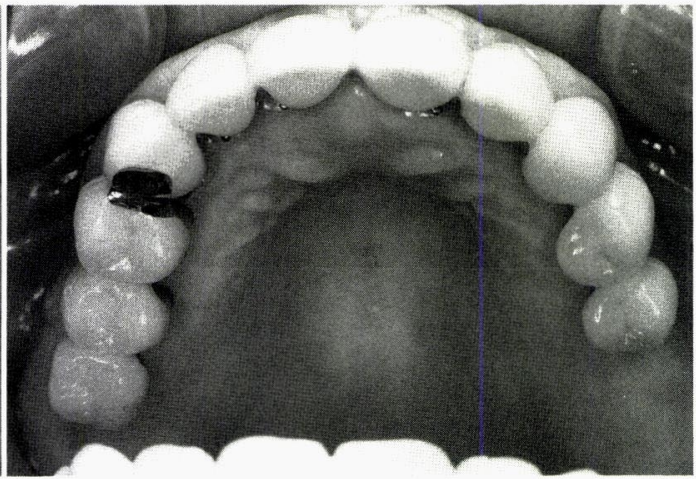

図 19

図 16２0＼cjkstart最終補経物

機能時にも審美的にも満足のいく形が

得られたと思われる。
た(図 9)。そして途中何度かマニピュレーション を行ったが, 結局最終的には円板のリキャプ チャーを締め, 咬合挙上とわずかに前方位をとる 咬合を与えることになった。

また途中の段階で，より咬合支持を安定させる ために, 上顎前歯部口蓋側を棚状にしてバーチカ ルストップに参加させた.さらに下顎が遠心にシ ルトしないようにするため, クロージャーストッ 
パーとイコライザーをつけた（図 10).

そのような試行錯誤をしながら初診より約 2 年 で, ようやく顎関節も安定を得られた。

\section{2. 歯周治療}

徹底的な初期治療の後に再評価を行なった。 そ して $5 \mid 4$ に扔いては，骨のレベリングのための歯 牙の延出を行なった(図 11).また，ポケットの除 去およびメインテナンスのしやすい歯周環境をつ くるための歯周外科をほほ全䫛にわたって行なっ た（図 12, 13).

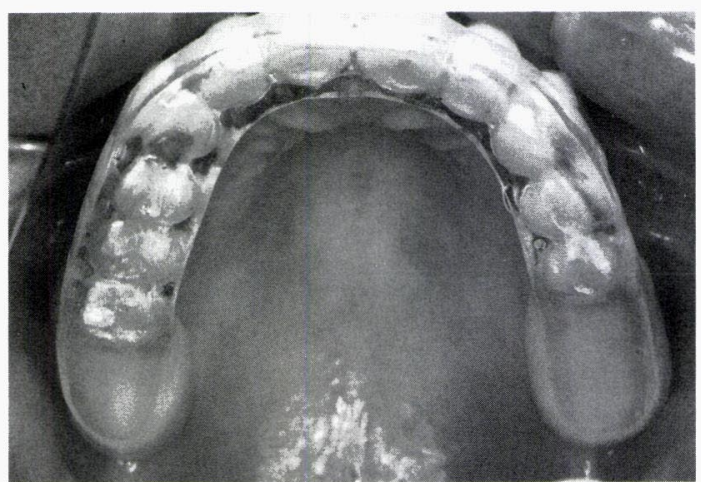

図 21 夜間装着するスプリントは臼歯部に少し長 くしてある.

\section{3. 最終補緅}

十分な歯肉の成熟を待ち（図 14，15）また顎関 節の安定を確認した上で, 最終印象に入った. プ ロビジョナルレストレーションによる考察の結 果, 最後方である $5 \mid 4$ にはフィッシュテールムー ブメントによるセメントのウォッシュアウトが起 こりやすかったため，グルーブを何本か入れてリ テンションを高めた. 最終印象は八イドロコロイ ドによるウェットテクニックで行なった. すべて 単冠にて試適し，ソルダリングインデックスをと り，それを蠟着していった. ビスケットベイクを 再び試適し,形態修正後リマウントし完成させた. 補綴設計は上顎が 6.5 延長のクロスアーチスプリ ントで, Key \& Keyweyを 43 間に入れた。こ れは方向性の問題と最終セメンティング時の浮き 上がり防止のためである。下顎は左側の Bridge 以外は全て単冠とした。技工士の努力もあり歯間 部の処理, 歯肉との調和, 色調など審美的に満足 のいくものになったと思われる(図 16〜20). 咬合 力と歯周支持能力のバランスを考慮して, 補綴物 を守ると同時に，下顎が後方にシフトするのを防 ぐためのスプリントを就寝時のみ装着した（図 21). 約 10 カ月の仮着の後に本 set を行った（図 22).

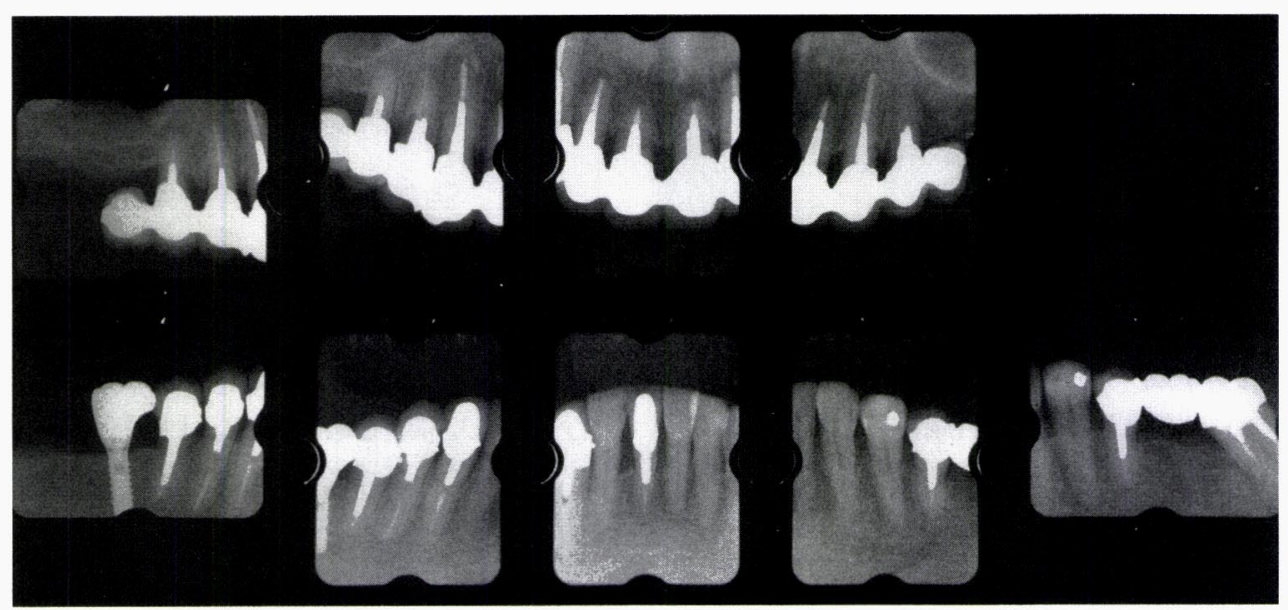

図 22 術後のX線

根尖にあったリージョンも縮小しており，骨の安定している状態がわかる. 


\section{考察}

本症例では通常の歯周補経と異なり，顎関節症 にいかに対処するかという，もう一つの大きな治 療が必要であり，筆者としても困難をきわめた。 最終的には関節円板のリキャプチャーをあきら め, バイラミナゾーンを圧迫しない位置に下顎頭 が安定するよう咬合の再構成を行なった。この際 留意したポイントとしては，上顎前歯部口蓋側を 棚状としてバーティカルストップに参加させたこ と，クロージャーストッパーとイコライザーをつ け，下顎が後方にシフトしないようにしたこと， 適性な咬合高径の回復とアンテリアガイダンスの 確立などがあげられる。

またポケット除去だけを目的として，根尖側移 動術などの歯周外科のみを行うのではなく，歯牙 の延出による骨のレベリング，さらに歯周外科時 の積極的な骨の形態修正などを合目的に行なうこ とにより，メインテナビリティの高い歯周環境を 付与した。ただし，左側上顎の予知性に乏しいた め,その部位に問題が生じたならばサイナスリフ トを含むインプラント外科処置を検討する必要が あると思われる。

\section{ま と め}

この症例は約 3 年がかりの治療となってしまっ
たが, 最終的には歯周組織および顎関節の安定が 得られ，また補綴的にも満足のいく形が得られた と思われる.しかし今後それが長期にわたり維持 されていくには患者のプラークコントロール，お よび術者側での咬合のチェックなどのメインテナ ンスが不可欠であることは言うまでもない．現在 患者は 1 カ月に 1 回のペースでリコールしてい る。

\section{参考文献}

1）山崎長郎，本多正明：歯周補経. 第 1 歯科出版 (東京), 1990 。

2) 山崎長郎, 本多正明：歯周補経 II. 第 1 歯科出 版 (東京), 1992 .

3）寺西邦彦：ビジュアルセミナ一臨床咬合学入 門.クインテッセンス出版 (東京), 1992 .

4）佐藤直志：歯周補緅の臨床と手技.クインテッ センス出版 (東京), 1992 .

5）丸茂義二：頱関節治療の現在. 日本歯科評論 (東 京), No. 529 545, 1986 1988.

6）中沢勝宏：入門顎関節の臨床. 医歯薬出版（東 京), 1992.

7）中村公雄, 他：歯周外科の考え方と実際.クイ ンテッセンス出版 (東京), 1994.

\section{別刷請求先：羽兼雅広}

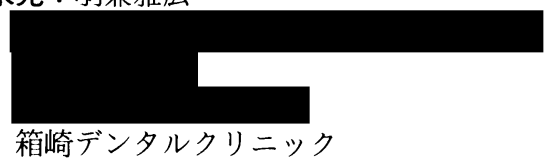

